\title{
Hybrid E. coli-Mitochondrial ribonuclease P RNAs are catalytically active
}

\author{
ELIAS SEIF, ALEXANDRE CADIEUX, and B. FRANZ LANG \\ Canadian Institute for Advanced Research, Robert-Cedergren Centre for Bioinformatics and Genomics, Département de Biochimie, Université de \\ Montréal, Montréal, Québec, H3T 1J4, Canada
}

\begin{abstract}
RNase $P$ is a ribonucleoprotein that cleaves tRNA precursors at their $\mathbf{5}^{\prime}$-end. Mitochondrion-encoded RNA subunits of mitochondrial RNase P (mtP-RNA) have been identified in jakobid flagellates such as Reclinomonas americana, in the prasinophyte alga Nephroselmis olivacea, and in several ascomycete and zygomycete fungi. While the structures of ascomycete mtP-RNAs are highly reduced, those of jakobids, prasinophytes, and zygomycetes retain most conserved features of their bacterial counterparts. Therefore, these mtP-RNAs might be active in vitro in the absence of a protein subunit, as are bacterial P-RNAs. Here we present a comparative structural analysis including seven newly characterized jakobid mtP-RNAs. We investigate ribozyme activities of mtP-RNAs and find that even the most bacteria-like molecules of jakobids are inactive in vitro. However, when certain domains of jakobid and $N$. olivacea mtP-RNAs are replaced with those from Escherichia coli, these hybrid RNAs show catalytic activity. In vitro mutagenesis of these hybrid mtP-RNAs shows that various structural elements play a critical role in ribozyme catalysis and provide further support for the presence of these elements in mtP-RNAs. These include GNRA tetraloops in helix P14 and P18 of Jakoba libera, and a remnant P3 pairing in Seculamonas ecuadoriensis. Finally, we will discuss reasons for the failure of mtP-RNAs to show catalytic activity in the absence of P-proteins based on our mutagenesis analysis.
\end{abstract}

Keywords: jakobids; mitochondria; RNase P; RNA secondary structure; tetraloop motifs

\section{INTRODUCTION}

RNase $\mathrm{P}$ is an endonuclease that cleaves $5^{\prime}$ leader sequence from tRNA precursors. It is usually composed of an RNA component (P-RNA) and one or several protein subunits (P-proteins) (Altman et al. 1995; Frank and Pace 1998; Hartmann and Hartmann 2003).

P-RNA genes $(r n p B)$ have been identified in numerous species from all domains of life, also including plastids (Brown 1999) and mitochondria (Seif et al. 2003, 2005). When present, the P-RNA subunit seems indispensable for the endonucleolytic activity of RNase P (e.g., Stark et al. 1978; Gardiner and Pace 1980; Kline et al. 1981; Hollingsworth and Martin 1986; Jayanthi and Van Tuyle 1992; Baum et al. 1996; Lee et al. 1996a; Han et al. 1998;

Reprint requests to: B. Franz Lang, Canadian Institute for Advanced Research, Robert-Cedergren Centre for Bioinformatics and Genomics, Département de Biochimie, Université de Montréal, 2900 Boulevard Edouard-Montpetit, Montréal, Québec, H3T 1J4, Canada; e-mail: Franz. Lang@Umontreal.ca; fax: (514) 343-2210.

Article published online ahead of print. Article and publication date are at http://www.rnajournal.org/cgi/doi/10.1261/rna.52106.
Vainauskas et al. 1998; Thomas et al. 2000; Stathopoulos et al. 2001). In all tested bacteria and some archaebacteria (Methanobacteria, Thermococci, and Halobacteria), even P-RNA alone is able to catalyze $5^{\prime}$ tRNA processing in vitro, in the absence of a P-protein (Guerrier-Takada et al. 1983; Gardiner et al. 1985; Pannucci et al. 1999; Wagner et al. 2001).

Comparative studies suggest that P-RNAs from all domains of life are homologs, sharing up to five sequence motifs (CRI-V; Fig. 1; Chen and Pace 1997), a cage-shaped pseudoknot (pairings P1-P4) (Forster and Altman 1990), a four-way junction region including pairings P7-P10, and a large internal loop including P11-P14 (Chen and Pace 1997). Escherichia coli P-RNA (M1 RNA) has been studied in much detail. Secondary and tertiary RNA structure models have been established based on in vitro mutagenesis, enzymatic probing, and cross-linking experiments (Brown et al. 1996; Westhof et al. 1996; Haas and Brown 1998; Massire et al. 1998). Fe(II)-EDTA protection experiments demonstrate that E. coli (and Bacillus subtilis) P-RNAs can be dissected into two modules with independent tertiary architectures (Loria and Pan 1996). The 
A
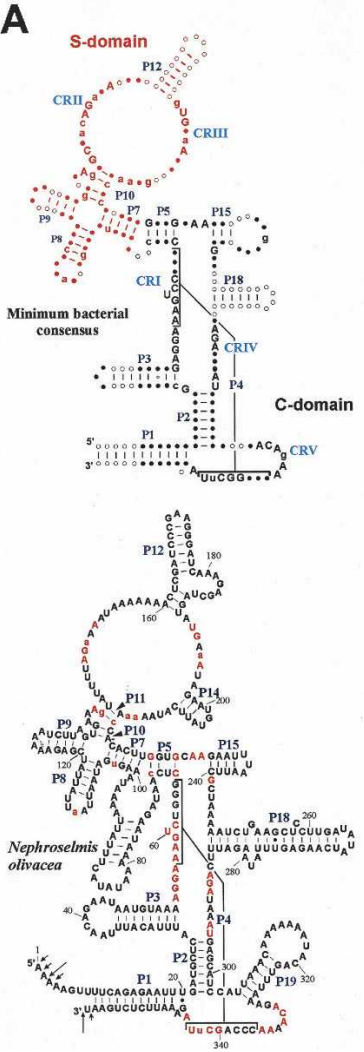
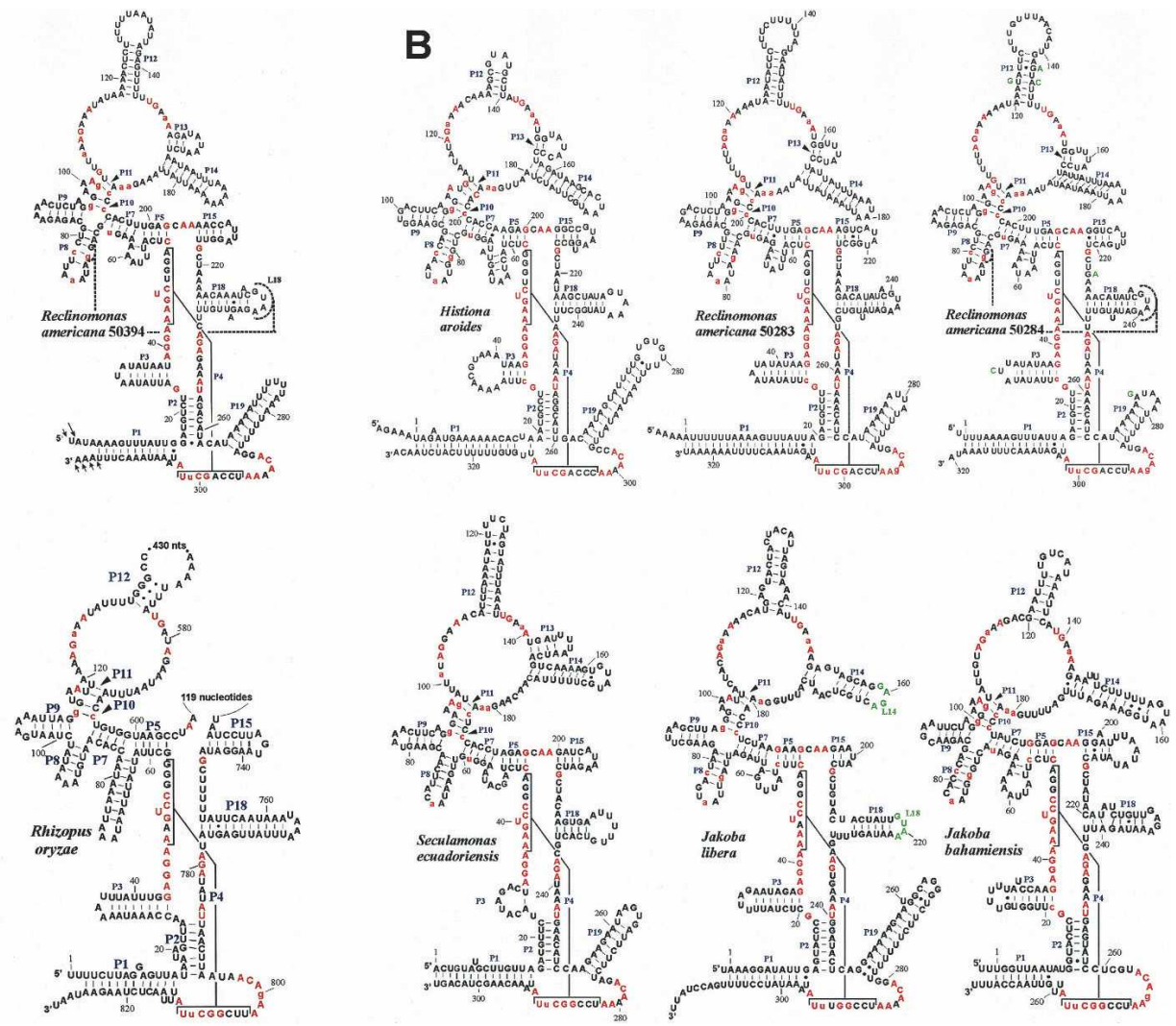

FIGURE 1. Secondary structure models of bacteria-like mtP-RNAs. (A) Minimum bacterial consensus (Brown et al. 1994) and mtP-RNA secondary structure models for R. americana \#50394, N. olivacea (Turmel et al. 1999) and Rhizopus oryzae (Seif et al. 2005). The S-domain is shown in red, and the C-domain is in black. Universally conserved motifs are presented as described by (Chen and Pace 1997). The arrows pinpoint experimentally determined RNA termini; the arrow length is proportional to the percentage of molecules ending at a given position. ( $B$ ) Secondary structure models for mtP-RNAs of the jakobids Histiona aroides \#50634, R. americana \#50283, R. americana \#50284, S. ecuadoriensis, $J$. libera, and J. bahamiensis. In $R$. americana \#50284, nucleotides in green denote the few sequence differences compared to Reclinomonas sp. \#50633. Positions in red are invariant or highly conserved in the minimum bacterial consensus. Uppercase letters indicate $100 \%$; lowercase, $>80 \%$ conservation of the minimum bacterial consensus sequence. Loops in green (L14 and L18) are GNRA motifs tested by mutational analysis (see Fig. 4). Potential L18/P8 interactions are shown by broken lines.

specificity, or S-, domain binds the T-stem-loop region of a pre-tRNA substrate, whereas the catalytic, or C-, domain carries the active site that consists of the pairing $\mathrm{P} 4$ and the junction J3/4 between P3 and P4 (Fig. 1; Guerrier-Takada and Altman 1992; Christian et al. 2000; Kaye et al. 2002; Tanaka et al. 2004a). In most bacteria including E. coli, the C-domain further interacts with the $3^{\prime}$ terminal RCCA sequence of the tRNA via a GGU motif in the internal loop between P15 and P16 (Kirsebom and Svard 1994; Kufel and Kirsebom 1998; Brannvall et al. 2004). Phylogenetic comparative studies and cross-linking experiments in E. coli suggest that $\mathrm{C}$ - and $\mathrm{S}$-domains interact through tertiary interactions of GNRA tetraloops (L18/P8 and L9/P1) (Brown et al. 1996; Massire et al. 1997), and that similar interactions occur within the S-domain (L14/P8 and L13/ P12). These interactions are confirmed in a recent study of the crystal structure of P-RNA from the bacterium Thermotoga maritima (Torres-Larios et al. 2005). Tetraloops of the GNRA-type confer thermodynamic stability on short
RNA double helices (Heus and Pardi 1991), and stabilize tertiary structures of large RNAs by intramolecular interactions (Jaeger et al. 1994; Murphy and Cech 1994; Cate et al. 1996). GNRA motifs also contribute to the catalytic activity of P-RNA, as shown by in vitro mutagenesis of the E. coli molecule: Substitution of certain GNRA by UNCG tetraloops significantly reduces P-RNA activity (PomeranzKrummel and Altman 1999).

Across eukaryotes, secondary structure models of mitochondrial P-RNAs (mtP-RNAs) deviate to various degrees from the established minimum bacterial consensus (Fig. 1A; Lang et al. 1997), reflecting consecutive losses of structural elements from an ancestral $\alpha$-proteobacteriumlike P-RNA (Seif et al. 2003, 2005). In budding yeasts and in the zygomycete Smittium culisetae, secondary structures of mtP-RNAs are reduced to two elements only: P1 and P4 (Seif et al. 2003, 2005; Talla et al. 2005). In contrast, a bacteria-like mtP-RNA structure is found in the bacterivorous protist Reclinomonas americana (member of the 
jakobid flagellates), which also possesses the most bacterialike mitochondrial genome (Lang et al. 1997; Jacob et al. 2004). Reclinomonas mtP-RNA not only contains all structural elements of the minimum bacterial consensus but also a P19 helix otherwise typical for $\alpha$-proteobacterial P-RNAs (Fig. 1A,B). P19 is otherwise only present in the mtP-RNA of the (green algal) prasinophyte Nephroselmis olivacea (Turmel et al. 1999).

Whereas mtP-RNAs have been well studied in various fungi (Shu and Martin 1991; Wise and Martin 1991; Lee et al. 1996b; Seif et al. 2003, 2005), little is known about the bacteria-like mtP-RNAs in jakobids or N. olivacea. Jakobids contain the most bacteria-like mitochondrial genomes in eukaryotes. Studying this lineage provides an insight into the early stages of mitochondrial evolution and, in particular, that of mtRNase P. It is unknown whether these mtPRNAs, which have been assigned based on in silico analysis, are transcribed in vivo, and if so, whether they are catalytically active in vitro, in the absence of a protein subunit. In this study, we conducted comparative structural analyses of jakobid and $N$. olivacea mtP-RNAs, mapped 5' and $3^{\prime}$ termini for $R$. americana and $N$. olivacea mtP-RNAs, and tested the in vitro activity of the wild-type and various mutagenized hybrid molecules.

\section{RESULTS}

\section{Structural variation among jakobid mtP-RNAs}

Bacteria-like mtP-RNA have been previously identified in the jakobid $R$. americana \#50394 (Lang et al. 1997), in N. olivacea (Turmel et al. 1999), and in zygomycetes (Seif et al. 2005). To obtain additional data for the comparative analysis of this RNA molecule, we sequenced mitochondrial DNAs (mtDNAs) of seven other jakobids: $R$. americana \#50283, R. americana \#50284, Reclinomonas sp. \#50633, Histiona aroides, Seculamonas ecuadoriensis, Jakoba libera, and Jakoba bahamiensis (G. Burger and B.F. Lang, unpubl.). We located $r n p B$ genes in all jakobid mtDNAs, initially by searching for the conserved motifs CRI, CRIV, and CRV, the pseudo-knot $\mathrm{P} 4$, and the $\mathrm{P} 1$ pairing (Forster and Altman 1990; Chen and Pace 1997; Seif et al. 2003). (The multiple alignment of these sequences is available at http:// megasun.bch.umontreal.ca/People/lang/rnpB/secondary structuremodels.html.).

The complete predicted mtP-RNA secondary structures (Fig. 1B) are similar to those of $R$. americana \#50394 (Lang et al. 1997), containing all structural elements of the minimum bacterial consensus. The only minor deviation is a highly reduced $\mathrm{P} 3$ in $S$. ecuadoriensis (Fig. 1B). Following a comparative analysis of jakobid mtP-RNAs, we updated the previously published secondary structure model for $R$. americana \#50394 (Lang et al. 1997) by extending the P18 helix and by assigning a GNRA tetraloop in L18 that is conserved in jakobids (except in S. ecuador- iensis and $H$. aroides) (Fig. 1B). Note that P19 is present in jakobids (except J. bahamiensis) and in the prasinophyte mtP-RNAs.

To verify that the in silico predicted $r m p B$ genes of a jakobid representative ( $R$. americana \#50394) and $N$. olivacea are expressed in vivo, we mapped their precise termini by ligation of $5^{\prime}$ and $3^{\prime}$ ends, RT-PCR amplification, and sequencing of the amplification products. In both cases, the $5^{\prime}$ and $3^{\prime}$ extremities are moderately heterogeneous and match the ends inferred from the predicted secondary structure (Fig. 1A; Lang et al. 1999; Turmel et al. 1999).

\section{Native mtP-RNAs are catalytically inactive in vitro}

We tested the catalytic in vitro activity of seven mtP-RNAs, which contain all or most of the structural elements as defined in the minimum bacterial P-RNA consensus (Fig. $1 \mathrm{~A})$, i.e., the molecules of the jakobids $R$. americana \#50394, S. ecuadoriensis, J. libera, and J. bahamiensis, the prasinophyte $N$. olivacea, and the zygomycetes Rhizopus oryzae and Rhizopus oligosporus (Seif et al. 2005). The catalytic activity of the in vitro synthesized mtP-RNAs was tested using RNA precursors of mitochondrial tRNA ${ }^{\text {Pro }}$ from $R$. americana and $\mathrm{tRNA}^{\mathrm{Lys}}$ from $R$. oryzae as substrates. None of the listed mtP-RNAs exhibit a catalytic activity under any assay condition in which the similarly "reduced" archaeal or synthetic "micro" RNase P RNAs are active (Siegel et al. 1996; Pannucci et al. 1999), including a wide range of ribozyme concentrations, extreme salt concentrations, and addition of PEG. The activity of the $R$. americana \#50394 mtP-RNA was also tested in the presence of the E. coli protein subunit and in an in vivo complementation assay using an E. coli mutant with a defective (thermosensitive) P-protein (Baer et al. 1989). These assays also turned out negative (results of both experiments not shown).

\section{Fusions of mtP-RNAs with E. coli P-RNA are catalytically active}

To locate specific structural elements that are responsible for the inactivity of mtP-RNAs, we constructed chimeric RNA molecules by combining half molecules of E. coli and mtP-RNAs of the jakobids $R$. americana (ATCC 50394), J. libera, and S. ecuadoriensis, the prasinophyte N. olivacea, and the zygomycete $R$. oryzae, which has the least derived structure among Fungi (Seif et al. 2005).

C-type chimeras contain the most conserved structural elements of $\mathrm{mtP}-\mathrm{RNAs}$ and their equivalent of the catalytic C-domain (Fig. 1A), including P1-P4, P18, and P19; the remaining elements are from E. coli (Fig. 2A). C-type chimeras possess various degrees of in vitro activity, highest in J. libera, and followed in order by $R$. americana, S. ecuadoriensis, and N. olivacea (Table 1; Fig. 2B,C). The 

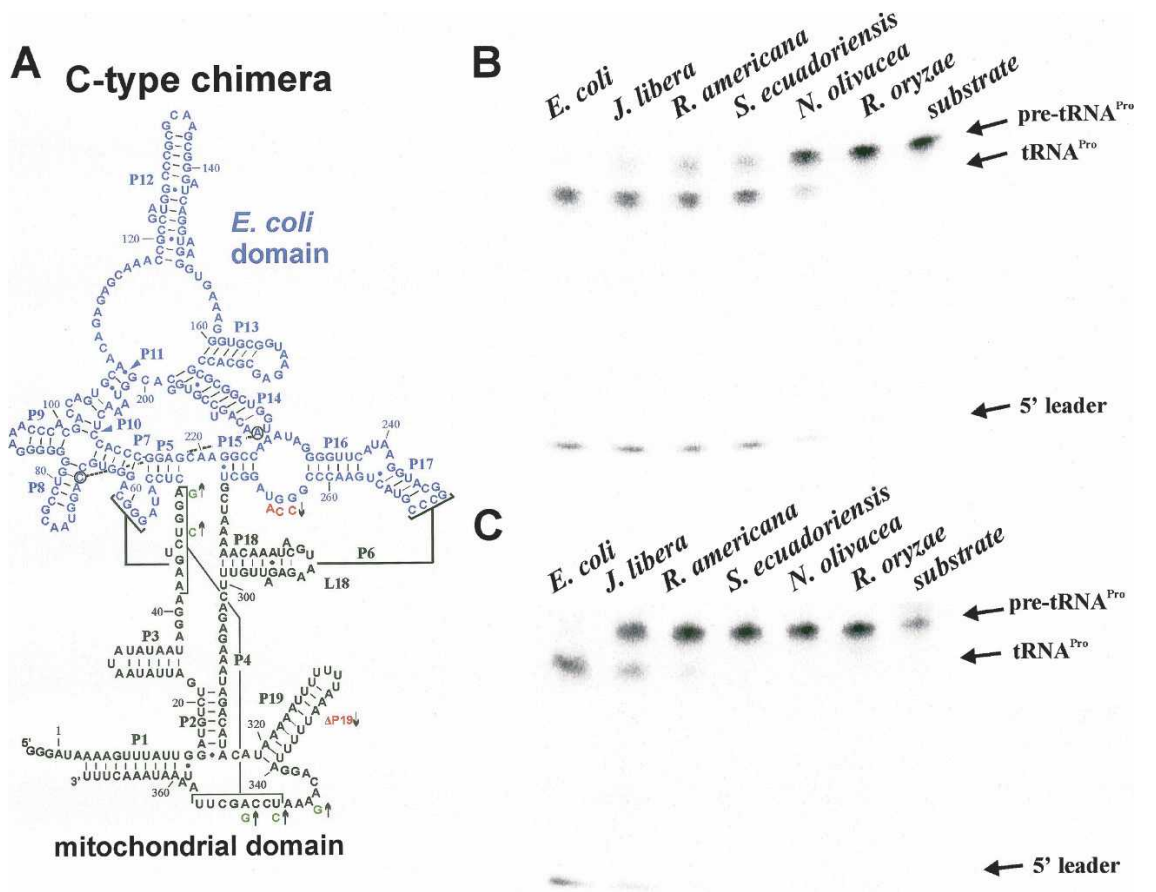

FIGURE 2. Activity assays of C-type chimeras. (A) Secondary structure model for C-type chimeras. The E. coli domain is shown in blue, and the mitochondrial domain is in black. Green nucleotides followed by upward arrows denote mutations that increase the catalytic activity of the chimera (see also Table 2). Red nucleotides followed by downward arrows indicate mutations that decrease the catalytic activity of the chimera (see also Table 2). $\Delta \mathrm{P} 19$, deletion of the P19 helix. (B) Catalytic assays of C-type chimeras with pre-tRNA ${ }^{\text {Pro }}$, under conditions optimal for archaebacterial P-RNAs. The substrate (1000 dpm) was incubated at $37^{\circ} \mathrm{C}$ for $18 \mathrm{~h}$ in the presence of $100 \mathrm{nM}$ ribozyme in $300 \mathrm{mM} \mathrm{MgCl}, 2.5 \mathrm{M}$ ammonium acetate $\left(\mathrm{NH}_{4} \mathrm{OAc}\right), 50 \mathrm{mM}$ Tris $(\mathrm{pH} 8), 0.1 \%$ SDS, and $0.05 \%$ Nonidet P-40. All tested constructs except the Rhizopus oryzae chimera are active. The positive control is with E. coli P-RNA (10 nM); the negative control contains substrate tRNA precursor only. (C) Catalytic assays of C-type chimeras with pre-tRNA ${ }^{\text {Pro }}$, under conditions optimal for bacterial P-RNAs (50 mM Tris at pH 7.5, $100 \mathrm{mM} \mathrm{NH}_{4} \mathrm{Cl}, 110 \mathrm{mM} \mathrm{MgCl}_{2}$ ). The ribozyme concentrations were as in Figure 2B. Under these conditions, only the J. libera and R. americana \#50394 chimeras are catalytically active.

chimera containing $R$. oryzae mtP-RNA is inactive. In Stype chimeras, the catalytic C-domain is from E. coli, and the residual elements are from mitochondrial molecules (Fig. 3A). In this configuration, the R. americana construct has the highest catalytic activity, followed by J. libera and S. ecuadoriensis, while that of $N$. olivacea is inactive (Fig. 2B,C). S-type chimeras are only active at high salt concentrations and require $\sim 10$ times higher ribozyme concentrations to achieve levels of activity comparable to C-type constructs (Fig. 2B,C).

In the presence of $1 \mathrm{nM}$ of E. coli P-protein and $0.1 \mathrm{nM}$ of chimera P-RNA, a slight activity increase was only detected in S-type chimera of $R$. americana. When the $\mathrm{P}$-protein and P-RNA concentrations were raised to $5 \mathrm{nM}$ and $0.5 \mathrm{nM}$, respectively, activities of S-type chimeras increased strongly for the $R$. americana and moderately for J. libera (Fig. 3C).

Both C- and S-type chimeras of R. americana are able to complement an E. coli mutant with a defective (thermo- sensitive) P-protein at the nonpermissive temperature (Baer et al. 1989), demonstrating that the chimeric RNAs are not only active under the nonphysiological in vitro conditions but also in vivo (Fig. 4).

\section{Mutations in GNRA tetraloops reduce catalytic activity}

GNRA tetraloops, which are highly conserved and functionally important in bacterial P-RNAs (Brown 1999; Pomeranz-Krummel and Altman 1999), are only present in some jakobid mtP-RNAs (L18 in Reclinomonas and Jakoba species, L14 in Jakoba species, and L9 in Histiona aroides) (Fig. 1). In E. coli, mutations in the L14 and L18 GNRA motifs lead to the loss of catalytic activity at low $(<20 \mathrm{mM}) \mathrm{MgCl}_{2}$ concentration (Pomeranz-Krummel and Altman 1999). A corresponding mutation in J. libera C-type chimera has a similar effect: A GUAA to AUAA mutation in the L18 tetraloop has no significant effect on activities measured at $100 \mathrm{mM}$ $\mathrm{MgCl}_{2}$ or higher (data not shown), but catalysis drastically decreases at low salt concentration $(\sim 20 \mathrm{mM} \mathrm{MgCl} 2)$ (Fig. 5A). A mutation of the L14 tetraloop in J. libera from GAGA to GAGG or AAGA (applied to the S-type chimera) significantly lowers the activity even at $300 \mathrm{mM} \mathrm{MgCl}_{2}$ (Fig. 5B). In turn, introduction of a GNRA motif in L9 of the R. americana S-type chimera increases its activity by more than twofold (Fig. 5C).

\section{Functionally important P3 remnant in mtP-RNA of S. ecuadoriensis}

P3 is found in all bacterial P-RNAs (Tanaka et al. 2004b) and in jakobid mtP-RNAs, varying in length between 5 and $8 \mathrm{bp}$, except in S. ecuadoriensis, where only a single A-U pair is predicted (Fig. 1B). To verify the functional significance of the postulated remaining $\mathrm{A}-\mathrm{U}$ pair, it was mutated to either an AxA mismatch or a $C-G$ base pair (Fig. 6B). At $300 \mathrm{mM} \mathrm{MgCl}_{2}$, the catalytic activity was high in all three cases. However, at $100 \mathrm{mM} \mathrm{MgCl}_{2}$, the activity decreases more than twofold in the AxA mutant but remains unaffected in the $C-G$ double mutation (Fig. 6). These results show that the remaining, single P3 WatsonCrick base pair in the S. ecuadoriensis mtP-RNA plays a critical role in the molecule's function. 
TABLE 1. Summary of species-specific catalytic activity for C- and S-type chimeras

\begin{tabular}{|c|c|c|c|}
\hline \multirow[b]{2}{*}{ Species } & \multicolumn{3}{|c|}{ Catalytic activity } \\
\hline & $\begin{array}{l}\text { C-type chimera high salt } \\
\text { conditions } 300 \mathrm{mM} \mathrm{MgCl} \\
2.5 \mathrm{M} \mathrm{CH}_{3} \mathrm{COONH} \mathrm{H}_{4}(50 \mathrm{mM} \\
\text { Tris at } \mathrm{pH} 8,0.1 \% \mathrm{SDS}, \\
\text { and } 0.05 \% \mathrm{NP}-40)\end{array}$ & $\begin{array}{c}\text { C-type chimera } \\
\text { intermediate salt conditions } \\
100 \mathrm{mM} \mathrm{MgCl}_{2} \\
100 \mathrm{mM} \mathrm{NH}_{4} \mathrm{Cl} \\
(50 \mathrm{mM} \text { Tris at } \mathrm{pH} 7.5)\end{array}$ & $\begin{array}{c}\text { S-type chimera high salt } \\
\text { conditions } 2.5 \mathrm{M} \mathrm{CH}_{3} \\
\mathrm{COONH}_{4}\left(50 \mathrm{mM}^{2} \text { Tris at }\right. \\
\mathrm{pH} 8,0.1 \% \\
\text { SDS, and } 0.05 \% \mathrm{NP}-40)\end{array}$ \\
\hline R. americana & + & + & + \\
\hline J. libera & + & + & + \\
\hline S. ecuadoriensis & + & - & + \\
\hline N. olivacea & + & - & - \\
\hline R. oryzae & - & - & N.C. \\
\hline
\end{tabular}

These results are a summary of experiments shown in Figures 2, B and C, and 3B. (+) indicates detection of a positive result; (-), of a negative result. N.C. (not constructed), no S-type chimera was designed for $R$. oryzae due to the high deviation in the secondary structure of the S-domain of its mtP-RNA.

\section{Other structural elements with impact on the catalytic activity of mtP-RNAs}

We further tested the impact of other features of jakobid mtP-RNAs, such as the presence of P19, a structural remnant from the $\alpha$-proteobacterial ancestor (except in $J$. bahamiensis). The deletion of P19 from the R. americana C-type chimera causes only an insignificant decrease of the initial catalytic activity (Table 2). This observation agrees with the evolutionary volatility of this variably present helix.

To further elucidate the failure of bacteria-like $\mathrm{mtP}$ RNAs to show catalytic activity in vitro in the absence of the protein subunit, we tested three different features encountered frequently in mtP-RNAs: first, the impact of deviations from the bacterial consensus sequence that are often noticed in mtP-RNAs (Seif et al. 2003); second, the impact of absence of the GGU motif in L15 that is responsible for binding of the $3^{\prime}$ terminal RCCA in most bacterial tRNAs; and finally, the impact of the high $A+U$ content, which in helical regions diminishes mtP-RNA stability.

The replacement of A292 in CRV of C-type chimera of $R$. americana with a $\mathrm{G}$ (preferred in $90 \%$ of bacterial $\mathrm{mtP}$ RNAs) increases the catalytic activity more then twofold at low $\mathrm{MgCl}_{2}$ concentrations (Table 2). Replacing the GGU motif by CCA (Fig. 2A) causes a twofold decrease in C-type chimera activity (Table 2), inferring that the absence of this motif is a handicap for the ribozyme activity of mtP-RNAs. Finally, augmenting the $\mathrm{G}+\mathrm{C}$ content in $\mathrm{P} 4$ of a C-type chimera by replacing two A-U with $\mathrm{G}-\mathrm{C}$ pairs (Fig. 2A), results in a twofold increase of the catalytic activity at an intermediate salt concentration (Table 2).

\section{DISCUSSION}

We have shown that even the most bacteria-like mtP-RNAs are catalytically inactive in vitro, which is likely due to the cumulative effect of (1) their relatively high $\mathrm{A}+\mathrm{U}$ content

TABLE 2. Effect of mutations in R. americana C-type chimera

\begin{tabular}{|c|c|c|c|}
\hline \multirow[b]{2}{*}{ Mutations } & \multicolumn{3}{|c|}{ Percentage of cleaved substrate } \\
\hline & $\begin{array}{c}\text { High salt conditions } \\
300 \mathrm{mM} \mathrm{MgCl}_{2}(50 \mathrm{mM} \\
\text { Tris at } \mathrm{pH} 8,0.1 \% \mathrm{SDS}, \\
\text { and } 0.05 \% \text { NP-40) }\end{array}$ & $\begin{array}{l}\text { Intermediate salt conditions } \\
\qquad 100 \mathrm{mM} \mathrm{MgCl}_{2} \\
100 \mathrm{mM} \mathrm{NH}_{4} \mathrm{Cl} \\
(50 \mathrm{mM} \text { Tris at } \mathrm{pH} 7.5)\end{array}$ & $\begin{array}{c}\text { Low salt conditions } \\
20 \mathrm{mM} \mathrm{MgCl}_{2} \\
100 \mathrm{mM} \mathrm{NH}_{4} \mathrm{Cl} \\
\text { (50 mM Tris at } \mathrm{pH} 7.5 \text { ) }\end{array}$ \\
\hline C-type chimera & $72 \%$ & $15 \%$ & $5 \%$ \\
\hline L15/16-CCA & $37 \%$ & - & - \\
\hline$\Delta \mathrm{P} 19$ & $57 \%$ & - & - \\
\hline$P 4 G+C$ rich & $73 \%$ & $30 \%$ & $7 \%$ \\
\hline A-G 292 & $82 \%$ & $13 \%$ & $13 \%$ \\
\hline
\end{tabular}




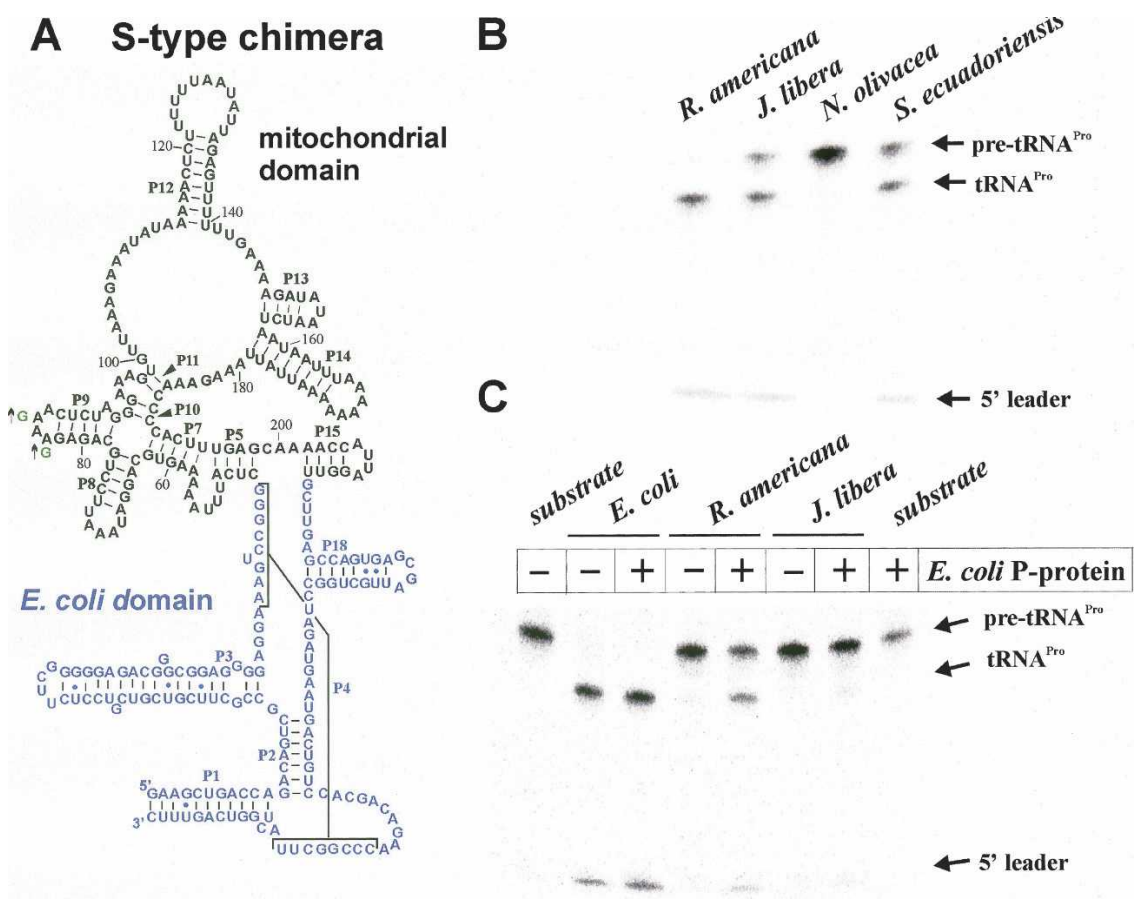

FIGURE 3. Activity assays of S-type chimeras. (A) Secondary structure model for S-type chimeras. The E. coli domain is shown in blue, and the mitochondrial domain is in black. Green nucleotides followed by upward arrows represent mutations that cause an increase in the catalytic activity of the chimera. (B) Catalytic assays of S-type chimeras with pre-tRNA ${ }^{\text {Pro }}$ and pre-tRNA ${ }^{\text {Lys }}$, at salt conditions optimal for archaebacterial RNase P. Substrate (1000 dpm) was incubated at $37^{\circ} \mathrm{C}$ for $18 \mathrm{~h}$ in the presence of $1 \mu \mathrm{M}$ of ribozyme, in $300 \mathrm{mM} \mathrm{MgCl} 2,2.5 \mathrm{M}$ $\mathrm{NH}_{4} \mathrm{OAc}, 50 \mathrm{mM}$ Tris (pH 8), $0.1 \%$ SDS and $0.05 \%$ Nonidet P-40. J. libera and R. americana \#50394 chimeras have the highest catalytic activity, followed by J. libera and S. ecuadoriensis; the N. olivacea construct is inactive. (C) Catalytic assays of S-type chimeras in the presence of E. coli P-protein. The assays were performed as described in Materials and Methods except that the concentrations of P-RNAs and P-protein were fivefold higher.

and low thermodynamic stability; (2) the absence of certain GNRA motifs, reducing the overall strength of tertiary interactions; (3) the absence of the GGU motif in L15/L16, which is involved in substrate binding of the $E$. coli molecule; and (4) deviations from the catalytically important bacterial consensus sequences (as demonstrated here with CRV). Any of these factors alone is not responsible for the lack of activity of mtP-RNAs, since also a "micro P-RNA" of E. coli lacking several GNRA motifs and P6 (Siegel et al. 1996) is still catalytically active and because minor deviations from the consensus sequences are also tolerated in bacterial P-RNAs (Rasmussen and Nolan 2002).

\section{MtP-RNAs are catalytically active in vitro, in E-coli/mtP-RNA chimeras}

The jakobid and N. olivacea mtP-RNAs retain sufficient structural features that allow restoration of their activity following partial replacements with $E$. coli sequences. The activities of these chimeras essentially correlate with (1) the overall degree of structural conservation of mtP-RNAs (with respect to their bacterial counterparts) and (2) the presence of features that stabilize RNA structure, such as high G + $\mathrm{C}$ content in helices, and tetraloops.

Both types of chimeras are catalytically active in jakobids. Yet, C-type chimeras are an order of magnitude more active than S-type chimeras, likely because their mitochondrial C-domain is most conserved. In fact, the S-domain of mtP-RNAs is highly variable in all species, especially in fungi, where some structural elements have been lost several times independently in the course of mitochondrial evolution (Seif et al. 2003). It is therefore not surprising that the N. olivacea C-type chimera is active, but that the S-type chimera lacks catalytic activity because its S-domain lacks $\mathrm{P} 13$, has a very short P14, and contains a 30-nucleotide (nt) insertion between P5 and P7.

\section{Potential tertiary interactions and stability of secondary structure in mtP-RNAs}

We note that the J. libera C-type chimera has the highest activity among all chimeras, which we attribute to the relatively high $\mathrm{G}+\mathrm{C}$ content in the helical regions of its mtP-RNA. This view is supported by an experiment with the $R$. americana C-type chimera in which two $\mathrm{A}-\mathrm{U}$ pairs in $\mathrm{P} 4$ are exchanged by $\mathrm{G}-\mathrm{C}$ pairs, resulting in an increase of catalytic activity (Table 2).

In addition, tertiary interactions mediated by GNRA motifs are crucial for the correct folding of P-RNAs into functional molecules (Pomeranz-Krummel and Altman 1999). Results from mutational experiments conducted on mitochondrial GNRA tetraloops are in line with this observation, suggesting possible long-range interactions with $\mathrm{P} 8$, as in E. coli and Thermotoga maritime (Brown et al. 1996; Torres-Larios et al. 2005): Their elimination in L14 and L18 of S-type and C-type chimeras of J. libera diminishes catalytic activity, whereas mutation of the L9 tetraloop sequence AAAA to GAGA in S-type chimera of $R$. americana results in an increase.

\section{Importance of P-proteins for mitochondrial RNase $P$ activity}

All tested mtP-RNAs are catalytically inactive in vitro and, in this respect, resemble those from eukaryotes (i.e., nucleus-encoded), chloroplasts, and most archaebacteria that also require protein subunits for in vitro activity. We 


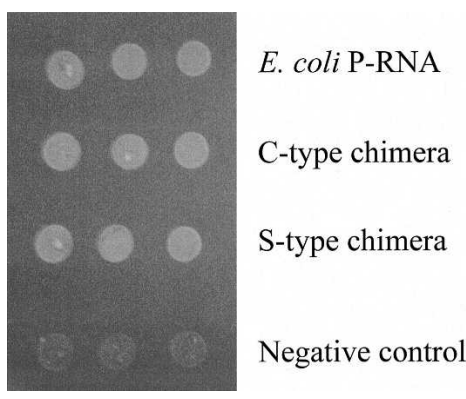

FIGURE 4. In vivo complementation assays of C- and S-type chimeras. E. coli P-RNA (positive control) and the R. americana $\mathrm{C}$ - and S-type chimeras were cloned downstream of a T7 promoter in an E. coli plasmid vector ( $\mathrm{pFBS}$ ) carrying the ampicillin resistance gene. Transformants of the three constructs and a negative control (plasmid without insert) were deposited three times independently on LB agar plates supplemented with antibiotics (for more details, see Materials and Methods). The picture was taken after overnight incubation at $43^{\circ} \mathrm{C}$.

have therefore conducted complementation experiments of $\mathrm{mtP}-\mathrm{RNAs}$ with the purified E. coli P-protein.

Whereas the E. coli P-protein does not reconstitute the activity of native mtP-RNAs, our results show that the in vitro catalytic activities of $R$. americana and J. libera S-type (but not C-type) P-RNA chimeras significantly increase in the presence of the E. coli P-protein. We think that this activation is favored by binding of the P-protein to the bacterial C-domain of the chimera that is also known to bind the P-protein in vitro (Loria and Pan 2001).

Overexpression of both $R$. americana chimeras complements a thermosensitive $E$. coli mutant that carries a point mutation in the protein subunit, implying that the $\mathrm{mtP}$ RNA chimeras interact with the E. coli P-protein in vivo. We interpret the activity of C-type chimera in the in vivo assay (and lack of activity in vitro) by differences in RNA and in protein folding and binding conditions.

\section{Conclusions}

In the course of evolution, mtP-RNAs have progressively lost structural elements that are conserved among their bacterial counterparts. We posit that this loss of RNA domains is compensated by proteins, a process that may ultimately lead to a protein-only RNase P. Currently, only one $\mathrm{mtP}$-protein has been identified in S. cerevisiae that is 10 times larger than in bacteria (Morales et al. 1992). In other instances, mitochondrial RNase has been purified and shown to contain multiple protein subunits (e.g., Marchfelder and Brennicke 1994; Lee et al. 1996a), but these remain unidentified. Evidently, we require information on mitochondrial P-proteins from a wide range of species covering various degrees of mtP-RNA reduction to better understand functional aspects, as well as test the hypothesis of a functional shift from RNA to protein during evolution.

\section{MATERIAL AND METHODS}

\section{Cell cultures and nucleic acid extractions}

An axenic strain of $N$. olivacea (NIES-484, a prasinophyte green alga distributed by the National Institute for Environmental Forum, Japan) was kindly provided by Drs. M. Turmel and C. Lemieux (Université Laval). Cells from this species were grown as previously described (Turmel et al. 1999). The jakobids Reclinomonas americana (New Zealand strain; ATCC 50,394), $R$. americana (ATCC 50,283), R. americana (ATCC 50,284), Reclinomonas sp. (ATCC 50,633), Histiona aroides (ATCC 50,634), and Seculamonas ecuadoriensis (ATCC 50,688) were grown in WCL medium, whereas the two jakobids adapted to saline growth conditions, Jakoba libera (ATCC 50,422) and Jakoba bahamiensis (ATCC 50,695), were cultivated in F/2 medium. The recipes for these growth media are posted at http://megasun.bch.umontreal.ca/ People/lang/FMGP/methods.html. For large-scale cultures, jakobids were incubated in 2.5 - $\mathrm{L}$ culture flasks under gentle shaking at $\sim 24^{\circ} \mathrm{C}$ and were daily fed with live Enterobacter aerogenes bacteria (ATCC 13,048). When cells reached the late logarithmic growth phase (after $\sim 5 \mathrm{~d}$ ), they were harvested by centrifugation, and nucleic acids were extracted as described (Seif et al. 2003).

\section{MtP-RNA 5' and 3' end mapping}

About $10 \mu \mathrm{g}$ of mitochondrial RNA were used to determine the precise $5^{\prime}$ or $3^{\prime}$ ends of mtP-RNAs by RNA ligation, RT-PCR

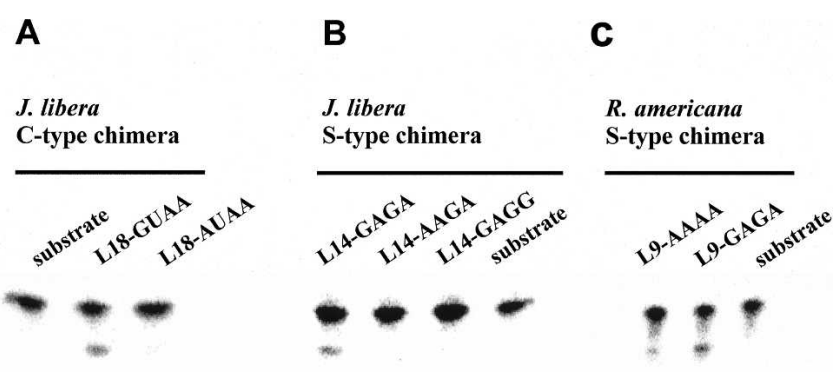

FIGURE 5. Catalytic assays of GNRA tetraloop mutants. (A) Assays for mutants in L18 of J. libera C-type chimera. Experiments with the respective wild-type (GUAA) and mutant sequences (AUAA) are labeled in the figure. The negative control lacks ribozyme. The assays were performed with $100 \mathrm{nM}$ of P-RNA, at $37^{\circ} \mathrm{C}$ for $2 \mathrm{~h}$ with 1000 $\mathrm{dpm}$ of pre-tRNA ${ }^{\text {Pro }}$ in a buffer containing $20 \mathrm{mM} \mathrm{MgCl}_{2}, 2.5 \mathrm{M}$ $\mathrm{NH}_{4} \mathrm{Cl}, 50 \mathrm{mM}$ Tris ( $\mathrm{pH} 8$ ), $0.1 \%$ SDS and $0.05 \%$ Nonidet P-40. (B) Assays of an L14 mutant of the J. libera S-type chimera. Experiments with the wild-type (GAGA) and mutant sequence (AAGA and GAGG) are labeled in the figure. In the lane labeled substrate, no ribozyme was added. The assay conditions were $1 \mu \mathrm{M}$ of ribozyme for $18 \mathrm{~h}$ at $37^{\circ} \mathrm{C}$, with the conditions optimal for archaebacterial P-RNAs (see Materials and Methods). (C) Assays of an L9 tetraloop mutant of the R. americana S-type chimera. Experiments with the wild-type tetraloop (AAAA) and the mutant sequence (GAGA) are labeled in the figure. In the lane labeled substrate, no ribozyme was added. Assay conditions are otherwise the same as described in $B$. 
A

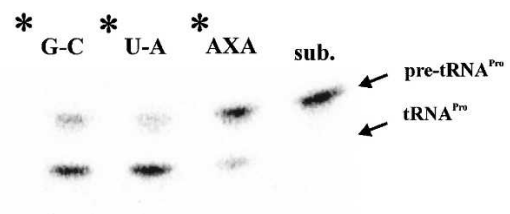

B

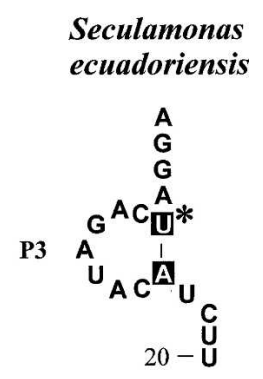

FIGURE 6. $\mathrm{P} 3$ mutagenesis in $S$. ecuadoriensis. (A) Assays for mutants of the postulated single P3 base pair. The postulated base pair is marked with an asterisk $\left.{ }^{*}\right)$. Ribozymes $(100 \mathrm{nM})$ were incubated with $1000 \mathrm{dpm}$ of pre-tRNA ${ }^{\text {Pro }}$ in a buffer containing $100 \mathrm{mM}$ $\mathrm{MgCl}_{2}, 2.5 \mathrm{M} \mathrm{NH}_{4} \mathrm{OAc}, 50 \mathrm{mM}$ Tris (pH 8), $0.1 \%$ SDS, and $0.05 \%$ Nonidet P-40. The ${ }^{\star}$ AXA mutant has a twofold decrease in catalytic activity compared to the ${ }^{*} \mathrm{G}-\mathrm{C}$ mutant and the ${ }^{*} \mathrm{U}-\mathrm{A}$ wild-type sequence. "Sub." denotes substrate only (negative control). (B) Secondary structure model of P3 and surrounding nucleotides.

amplification, and cDNA sequencing, as previously described (Seif et al. 2003). Primer sequences for $R$. americana were $5^{\prime}$-TAAATGAGTCCAGACTTTCCT-3' and 5'-GAGCAAAACCATTAGGTTGCT-3'; and for N. olivacea, 5'-CTATTTCATACTAGCTCT-3' and 5'-GTGCAAGAATTTAATTCGCT-3'.

\section{Construction of chimeric P-RNAs}

The rmpB genes of E. coli, R. americana \#50394, J. libera, S. ecuadoriensis, $R$. oryzae, and $N$. olivacea were cloned into pFBS (a modified bluescript vector) and used as templates for the PCR amplifications described below.

The cloning vector was amplified together with one of the two (mitochondrial or E. coli) domains, which permits direct cloning of chimeric $r m p B$ genes after DNA ligation with a corresponding section of P-RNA. For construction of C-type chimeras (see Fig. $2 \mathrm{~A}$ for the precise extensions of the mitochondrial and bacterial sequences), mitochondrial P-RNAs were amplified to include P1P4, P18, P19, and J15/18. The respective E. coli P-RNA domain was amplified to include P5-P17. For S-type chimeras (see Fig. 3A), the amplified mitochondrial domain contained P5 and P7$\mathrm{P} 15$, whereas the E. coli domain comprised P1-P4, J15/18, and P18. All amplification products were end-repaired (unmodified T7 DNA polymerase from New England Biolabs, no. M02565S, plus the Klenow fragment from Roche, no. 1008404) at $14^{\circ} \mathrm{C}$ for $30 \mathrm{~min}$. After denaturation of the polymerases at $65^{\circ} \mathrm{C}$ for $10 \mathrm{~min}$, the DNA fragments were purified on low-melting agarose gel (FMC Bioproducts, no. 50102). The PCR product including the vector sequence was dephosphorylated with alkaline phosphatase (Boehringer Mannheim, no. 713023), followed by extraction with phenol/chloroform and ethanol precipitation, whereas the corresponding fragment containing the other half of the P-RNA sequence was phosphorylated with T4 polynucleotide kinase (USB, no. 27073602). The two fragments were ligated at $14^{\circ} \mathrm{C}$ overnight and transformed into E. coli. Finally, transformants were verified by DNA sequencing.

\section{In vitro synthesis of RNA and RNase P activity assays}

Internally radiolabeled precursor tRNA substrates and unlabeled P-RNAs were synthesized in vitro and purified as described previously (Jacob et al. 2004). DNA templates for in vitro RNA synthesis were prepared by PCR amplification of respective PRNA sequences, by inclusion of a T7 RNA polymerase promoter in one of the two PCR primers. Purified RNAs were dissolved in $1 \times$ PA buffer $\left(50 \mathrm{mM}\right.$ Tris at $\mathrm{pH} 7.5,100 \mathrm{mM} \mathrm{NH}_{4} \mathrm{Cl}, 10 \mathrm{mM}$ $\mathrm{MgCl}_{2}$ ), heated for $5 \mathrm{~min}$ at $65^{\circ} \mathrm{C}$, and then allowed to slowly cool to $37^{\circ} \mathrm{C}$.

The catalytic activity of P-RNAs was tested with the pre-tRNA substrate ( $\sim 1000 \mathrm{dpm}, 0.013 \mathrm{pmol})$ under two conditions: $(1)$ activity assays adapted to bacterial P-RNAs at intermediate salt conditions (Guerrier-Takada et al. 1986), including $1 \times$ PA buffer, $100 \mathrm{mM} \mathrm{MgCl}_{2}$, and 4\% PEG (polyethylene glycol), or (2) archaebacterial or high salt conditions $(50 \mathrm{mM}$ Tris at $\mathrm{pH} 8$, $300 \mathrm{mM} \mathrm{MgCl}_{2}$, $2.5 \mathrm{M} \mathrm{NH}_{4} \mathrm{OAc}, 0.1 \%$ SDS, and $0.05 \%$ Nonidet P-40) (Pannucci et al. 1999). For assays including the E. coli P-protein, $5 \mathrm{nM}$ of the protein was added to $0.5 \mathrm{nM}$ of P-RNA in binding buffer (20 mM HEPES- $\mathrm{KOH}$ at $\mathrm{pH} 8,400 \mathrm{mM} \mathrm{NH}_{4} \mathrm{OAc}$, $10 \mathrm{mM} \mathrm{Mg}(\mathrm{OAc})_{2}, 5 \%$ glycerol $)$, the mixture was heated for 5 min at $37^{\circ} \mathrm{C}$, and $1000 \mathrm{dpm}$ of substrate was added and incubated at $37^{\circ} \mathrm{C}$ overnight.

Reaction products were loaded on $7 \%$ denaturing polyacrylamide gels as described (Jacob et al. 2004), gels were exposed for 2 h on a BioRad molecular imaging screen K (no. 1707841), and images were developed using the BioRad molecular imager FX and analyzed with the "Quantity One" software.

\section{Genetic complementation assay}

E. coli BL21 carrying a rnpA mutation in the chromosome (C5 $\mathrm{R} 46 \mathrm{H}$ ) (Guerrier-Takada et al. 1995) and containing $\lambda$ prophages that encode T7 RNA polymerase were used for the genetic complementation assay. The permissive and nonpermissive temperatures for this E. coli strain are $30^{\circ} \mathrm{C}$ and $43^{\circ} \mathrm{C}$, respectively. This E. coli strain was transformed with plasmids encoding various mtP-RNA constructs and grown overnight at $30^{\circ} \mathrm{C}$ on LB media with $5 \mu \mathrm{g} / \mathrm{mL}$ tetracycline and $100 \mu \mathrm{g} / \mathrm{mL}$ ampicillin. Several independent transformants were isolated and grown on liquid LB media to an optical density of 0.7 at the permissive temperature. From each culture, $7.5 \mu \mathrm{L}$ was dropped on two (prewarmed) agar plates and incubated overnight, one at $30^{\circ} \mathrm{C}$ and the other at $43^{\circ} \mathrm{C}$. Genetic complementation by various $\mathrm{P}$ RNA constructs was assessed by comparison of growth at the two temperatures (Baer et al. 1989). Cells transformed with vector alone and a vector encoding E. coli P-RNA served as negative and positive controls.

\section{ACKNOWLEDGMENTS}

We thank Drs. G. Burger (Université de Montréal) and M.W. Gray (Dalhousie University) for comments on the manuscript, and Drs. Sidney Altman and Cecilia Guerrier-Takada (Yale University) for providing experimental protocols, E. coli P-protein, and the A49 mutant strain. We further acknowledge the excellent technical assistance of Jean-Francois Bouffard and Lise Forget. Salary and interaction support from the Canadian Institutes of Health Research (MOP 42475; BFL) and the Canadian 
Institute for Advanced Research (CIAR; BFL), and access to laboratory equipment and informatics infrastructure supplied by Genome Quebec/Canada are gratefully acknowledged.

Received February 4, 2006; accepted May 15, 2006.

\section{REFERENCES}

Altman, S., Kirsebom, L.A., and Talbot, S. 1995. Recent studies of RNase P. In tRNA structure, biosynthesis, and functions (eds. D. Soll and U. RajBhandry), pp. 67-78. American Society for Microbiology Press, Washington DC.

Baer, M.F., Wesolowski, D., and Altman, S. 1989. Characterization in vitro of the defect in a temperature-sensitive mutant of the protein subunit of RNase P from Escherichia coli. J. Bacteriol. 171: 68626866.

Baum, M., Cordier, A., and Schon, A. 1996. RNase P from a photosynthetic organelle contains an RNA homologous to the cyanobacterial counterpart. J. Mol. Biol. 257: 43-52.

Brannvall, M., Kikovska, E., and Kirsebom, L.A. 2004. Cross talk between the $+73 / 294$ interaction and the cleavage site in RNase $\mathrm{P}$ RNA mediated cleavage. Nucleic Acids Res. 32: 5418-5429.

Brown, J.W. 1999. The ribonuclease P database. Nucleic Acids Res. 27: 314.

Brown, J.W., Haas, E.S., Gilbert, D.G., and Pace, N.R. 1994. The ribonuclease P database. Nucleic Acids Res. 22: 3660-3662.

Brown, J.W., Nolan, J.M., Haas, E.S., Rubio, M.A., Major, F., and Pace, N.R. 1996. Comparative analysis of ribonuclease P RNA using gene sequences from natural microbial populations reveals tertiary structural elements. Proc. Natl. Acad. Sci. 93: 3001-3006.

Cate, J.H., Gooding, A.R., Podell, E., Zhou, K., Golden, B.L., Kundrot, C.E., Cech, T.R., and Doudna, J.A. 1996. Crystal structure of a group I ribozyme domain: Principles of RNA packing. Science 273: 1678-1685.

Chen, J.L. and Pace, N.R. 1997. Identification of the universally conserved core of ribonuclease P RNA. RNA 3: 557-560.

Christian, E.L., Kaye, N.M., and Harris, M.E. 2000. Helix P4 is a divalent metal ion binding site in the conserved core of the ribonuclease P ribozyme. RNA 6: 511-519.

Forster, A.C. and Altman, S. 1990. Similar cage-shaped structures for the RNA components of all ribonuclease $\mathrm{P}$ and ribonuclease MRP enzymes. Cell 62: 407-409.

Frank, D.N. and Pace, N.R. 1998. Ribonuclease P: Unity and diversity in a tRNA processing ribozyme. Annu. Rev. Biochem. 67: 153180.

Gardiner, K. and Pace, N.R. 1980. RNase P of Bacillus subtilis has a RNA component. J. Biol. Chem. 255: 7507-7509.

Gardiner, K.J., Marsh, T.L., and Pace, N.R. 1985. Ion dependence of the Bacillus subtilis RNase P reaction. J. Biol. Chem. 260: 54155419.

Guerrier-Takada, C. and Altman, S. 1992. Reconstitution of enzymatic activity from fragments of M1 RNA. Proc. Natl. Acad. Sci. 89: 1266-1270.

Guerrier-Takada, C., Gardiner, K., Marsh, T., Pace, N., and Altman, S. 1983. The RNA moiety of ribonuclease P is the catalytic subunit of the enzyme. Cell 35: 849-857.

Guerrier-Takada, C., Haydock, K., Allen, L., and Altman, S. 1986. Metal ion requirements and other aspects of the reaction catalyzed by M1 RNA, the RNA subunit of ribonuclease P from Escherichia coli. Biochemistry 25: 1509-1515.

Guerrier-Takada, C., Li, Y., and Altman, S. 1995. Artificial regulation of gene expression in Escherichia coli by RNase P. Proc. Natl. Acad. Sci. 92: 11115-11119.

Haas, E.S. and Brown, J.W. 1998. Evolutionary variation in bacterial RNase P RNAs. Nucleic Acids Res. 26: 4093-4099.

Han, S.J., Lee, B.J., and Kang, H.S. 1998. Purification and characterization of the nuclear ribonuclease $\mathrm{P}$ of Aspergillus nidulans. Eur. J. Biochem. 251: 244-251.
Hartmann, E. and Hartmann, R.K. 2003. The enigma of ribonuclease $\mathrm{P}$ evolution. Trends Genet. 19: 561-569.

Heus, H.A. and Pardi, A. 1991. Structural features that give rise to the unusual stability of RNA hairpins containing GNRA loops. Science 253: 191-194.

Hollingsworth, M.J. and Martin, N.C. 1986. RNase P activity in the mitochondria of Saccharomyces cerevisiae depends on both mitochondrion and nucleus-encoded components. Mol. Cell. Biol. 6: 1058-1064.

Jacob, Y., Seif, E., Paquet, P.O., and Lang, B.F. 2004. Loss of the mRNA-like region in mitochondrial tmRNAs of jakobids. RNA 10: 605-614.

Jaeger, L., Michel, F., and Westhof, E. 1994. Involvement of a GNRA tetraloop in long-range RNA tertiary interactions. J. Mol. Biol. 236: 1271-1276.

Jayanthi, G.P. and Van Tuyle, G.C. 1992. Characterization of ribonuclease P isolated from rat liver cytosol. Arch. Biochem. Biophys. 296: 264-270.

Kaye, N.M., Zahler, N.H., Christian, E.L., and Harris, M.E. 2002. Conservation of helical structure contributes to functional metal ion interactions in the catalytic domain of ribonuclease P RNA. J. Mol. Biol. 324: 429-442.

Kirsebom, L.A. and Svard, S.G. 1994. Base pairing between Escherichia coli RNase P RNA and its substrate. EMBO J. 13: 4870-4876.

Kline, L., Nishikawa, S., and Soll, D. 1981. Partial purification of RNase P from Schizosaccharomyces pombe. J. Biol. Chem. 256: 5058-5063.

Kufel, J. and Kirsebom, L.A. 1998. The P15-loop of Escherichia coli RNase P RNA is an autonomous divalent metal ion binding domain. RNA 4: 777-788.

Lang, B.F., Burger, G., O’Kelly, C.J., Cedergren, R., Golding, G.B., Lemieux, C., Sankoff, D., Turmel, M., and Gray, M.W. 1997. An ancestral mitochondrial DNA resembling a eubacterial genome in miniature. Nature 387: 493-497.

Lang, B.F., Gray, M.W., and Burger, G. 1999. Mitochondrial genome evolution and the origin of eukaryotes. Annu. Rev. Genet. 33:351-397.

Lee, Y.C., Lee, B.J., Hwang, D.S., and Kang, H.S. 1996a. Purification and characterization of mitochondrial ribonuclease $\mathrm{P}$ from Aspergillus nidulans. Eur. J. Biochem. 235: 289-296.

Lee, Y.C., Lee, B.J., and Kang, H.S. 1996b. The RNA component of mitochondrial ribonuclease $\mathrm{P}$ from Aspergillus nidulans. Eur. J. Biochem. 235: 297-303.

Loria, A. and Pan, T. 1996. Domain structure of the ribozyme from eubacterial ribonuclease P. RNA 2: 551-563.

- 2001. Modular construction for function of a ribonucleoprotein enzyme: The catalytic domain of Bacillus subtilis RNase P complexed with B. subtilis RNase P protein. Nucleic Acids Res. 29: 1892-1897.

Marchfelder, A. and Brennicke, A. 1994. Characterization and partial purification of tRNA processing activities from potato mitochondria. Plant Physiol. 105: 1247-1254.

Massire, C., Jaeger, L., and Westhof, E. 1997. Phylogenetic evidence for a new tertiary interaction in bacterial RNase P RNAs. RNA 3: $553-556$.

- 1998. Derivation of the three-dimensional architecture of bacterial ribonuclease P RNAs from comparative sequence analysis. J. Mol. Biol. 279: 773-793.

Morales, M.J., Dang, Y.L., Lou, Y.C., Sulo, P., and Martin, N.C. 1992. A $105-\mathrm{kDa}$ protein is required for yeast mitochondrial RNase $\mathrm{P}$ activity. Proc. Natl. Acad. Sci. 89: 9875-9879.

Murphy, F.L. and Cech, T.R. 1994. GAAA tetraloop and conserved bulge stabilize tertiary structure of a group I intron domain. J. Mol. Biol. 236: 49-63.

Pannucci, J.A., Haas, E.S., Hall, T.A., Harris, J.K., and Brown, J.W. 1999. RNase P RNAs from some Archaea are catalytically active. Proc. Natl. Acad. Sci. 96: 7803-7808.

Pomeranz-Krummel, D.A. and Altman, S. 1999. Verification of phylogenetic predictions in vivo and the importance of the tetraloop motif in a catalytic RNA. Proc. Natl. Acad. Sci. 96: 11200-11205. 
Rasmussen, T.A. and Nolan, J.M. 2002. G350 of Escherichia coli RNase $\mathrm{P}$ RNA contributes to $\mathrm{Mg} 2+$ binding near the active site of the enzyme. Gene 294: 177-185.

Seif, E.R., Forget, L., Martin, N.C., and Lang, B.F. 2003. Mitochondrial RNase P RNAs in ascomycete fungi: Lineage-specific variations in RNA secondary structure. RNA 9: 1073-1083.

Seif, E., Leigh, J., Liu, Y., Roewer, I., Forget, L., and Lang, B.F. 2005. Comparative mitochondrial genomics in zygomycetes: Bacterialike RNase P RNAs, mobile elements and a close source of the group I intron invasion in angiosperms. Nucleic Acids Res. 33: 734-744.

Shu, H.H. and Martin, N.C. 1991. RNase P RNA in Candida glabrata mitochondria is transcribed with substrate tRNAs. Nucleic Acids Res. 19: 6221-6226.

Siegel, R.W., Banta, A.B., Haas, E.S., Brown, J.W., and Pace, N.R. 1996. Mycoplasma fermentans simplifies our view of the catalytic core of ribonuclease P RNA. RNA 2: 452-462.

Stark, B.C., Kole, R., Bowman, E.J., and Altman, S. 1978. Ribonuclease P: An enzyme with an essential RNA component. Proc. Natl. Acad. Sci. 75: 3717-3721.

Stathopoulos, C., Tekos, A., Zarkadis, I.K., and Drainas, D. 2001. Extensive deproteinization of Dictyostelium discoideum RNase P reveals a new catalytic activity. Eur. J. Biochem. 268: 2134-2140.

Talla, E., Anthouard, V., Bouchier, C., Frangeul, L., and Dujon, B. 2005. The complete mitochondrial genome of the yeast Kluyveromyces thermotolerans. FEBS Lett. 579: 30-40.

Tanaka, T., Ando, T., Haga, S., and Kikuchi, Y. 2004a. Examining the bases of the J3/4 domain of Escherichia coli ribonuclease P. Biosci. Biotechnol. Biochem. 68: 1388-1392.
Tanaka, T., Kanda, N., and Kikuchi, Y. 2004b. The P3 domain of E. coli ribonuclease P RNA can be truncated and replaced. FEBS Lett. 577: 101-104.

Thomas, B.C., Chamberlain, J., Engelke, D.R., and Gegenheimer, P. 2000. Evidence for an RNA-based catalytic mechanism in eukaryotic nuclear ribonuclease P. RNA 6: 554-562.

Torres-Larios, A., Swinger, K.K., Krasilnikov, A.S., Pan, T., and Mondragon, A. 2005. Crystal structure of the RNA component of bacterial ribonuclease P. Nature 437: 584-587.

Turmel, M., Lemieux, C., Burger, G., Lang, B.F., Otis, C., Plante, I., and Gray, M.W. 1999. The complete mitochondrial DNA sequences of Nephroselmis olivacea and Pedinomonas minor. Two radically different evolutionary patterns within green algae. Plant Cell 11: $1717-1730$.

Vainauskas, S., Stribinskis, V., Padegimas, L., and Juodka, B. 1998. Partial characterization of the ribonuclease $\mathrm{P}$ from Tetrahymena pyriformis. Biochimie 80: 595-604.

Wagner, M., Fingerhut, C., Gross, H.J., and Schon, A. 2001. The first phytoplasma RNase P RNA provides new insights into the sequence requirements of this ribozyme. Nucleic Acids Res. 29: 2661-2665.

Westhof, E., Wesolowski, D., and Altman, S. 1996. Mapping in three dimensions of regions in a catalytic RNA protected from attack by an Fe(II)-EDTA reagent. J. Mol. Biol. 258: 600-613.

Wise, C.A. and Martin, N.C. 1991. Dramatic size variation of yeast mitochondrial RNAs suggests that RNase P RNAs can be quite small. J. Biol. Chem. 266: 19154-19157. 

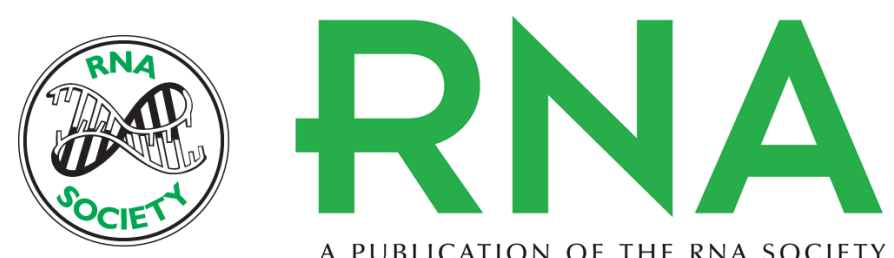

A PUBLICATION OF THE RNA SOCIETY

\section{Hybrid E. coli--Mitochondrial ribonuclease P RNAs are catalytically active}

Elias Seif, Alexandre Cadieux and B. Franz Lang

RNA 2006 12: 1661-1670

References This article cites 58 articles, 24 of which can be accessed free at:

http://rnajournal.cshlp.org/content/12/9/1661.full.html\#ref-list-1

\section{License}

Email Alerting Receive free email alerts when new articles cite this article - sign up in the box at the Service top right corner of the article or click here. 